\title{
封着用 $\mathrm{Fe}-29 \mathrm{Ni}-17 \mathrm{Co}$ 合金の高温酸化および ガラス封着性におよ添す添加元素の影響
}

\section{久世孝* 幕 内昭司 ${ }^{*}$ 松木俊治*}

Takashi Kuse, Teruji Makuuchi and Toshiharu Matsuki : Effects of Ce,Al and Si Additions on High Temperature Oxidation and Sealability of Fe-29 Ni-17 Co Sealing Alloy . High temperature oxidation and sealability of $\mathrm{Fe}-29 \mathrm{Ni}-17 \mathrm{Co}$ alloy containing $\mathrm{Ce}, \mathrm{Al}$ and $\mathrm{Si}$, which is used for hard glass sealing, have been investigated by means of thermobalance, scanning electron micrograph and $\mathrm{X}$-ray micro-analysis.

This alloy shows a good adherence between the oxide film and metal. As a result, the alloy shows good sealability. This can be attributed to the growth of the Si oxide layer between the oxide film and metal, and the internal oxidation of $\mathrm{Al}$ and $\mathrm{Si}$.

Oxide film consists chiefly of $\alpha-\mathrm{Fe}_{2} \mathrm{O}_{3}, \mathrm{Fe}_{3} \mathrm{O}_{4}$ and $\mathrm{CoO} \cdot \mathrm{Fe}_{2} \mathrm{O}_{3}$. At the initial stage of oxidation, the network of spinel type oxide builds up on the surface, the width of this oxide increases as oxidation proceeds. The activation energy for oxidation changes at about $900^{\circ} \mathrm{C}$, amounting to $61.9 \mathrm{kcal} / \mathrm{mol}$ on the high temperature side and $28.7 \mathrm{kcal} / \mathrm{mol}$ on the $10 \mathrm{w}$ temperature side. Oxidation rate is lower for this alloy in comparision with the rate of an alloy to which $\mathrm{Ce}, \mathrm{Al}$ and $\mathrm{Si}$ were not added.

(Received February 3, 1975)

\section{I. 緒言}

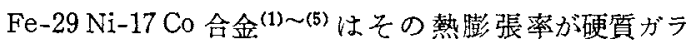
ス・セラミックのそれとよく一致していることから，硬質 ガラス怙よびセラミック封着合金として広く用いられてい る.

Fe-29 Ni-17Co 合金の成分と変態戌する報告 ${ }^{(6)(7)}$ ，合 金の処理およびガラスとの封着に関する報告(8)〜(11) は数多 く見られるが，微量含有元素の影響について調べたものは ほとんど見当たらない。

金属とガラスとの封着は実用的には金属を高温酸化し， 酸化膜とガラスとをなじま过るといら工程がとられる。封 着の信頼性は金属の酸化膜汇支配されることが多く，酸化 膜の性質が問題となる。.Fe-29 Ni-17 Co 合金は通常, 発泡 防止のため湿潤水素中で脱炭処理 ${ }^{(12)}$ を行ない，次いで大気 中で高温酸化しガラスとの封着に供されるが，酸化条件に よっては酸化膜は剥離し易くなることが知られている。

封着合金では地金との密着性が良く，ガラスとのなじみ の良い酸化膜が形成されることが望まれる ${ }^{(13)}$. 酸化膜の 性質は合金中の微量添加元素の影響を受けることが多い。 そこで, Fe-29 Ni-17 Co 合金炕 Ce と内部酸化することが 知られているAl，Si を添加したとき，高温酸化就よびガラ 不封着性にどのよらな影響をおよぼすがついて調べた。

\section{II．試料および実験方法}

市販の封着用 $\mathrm{Fe}-29 \mathrm{Ni}-17 \mathrm{Co}$ 合金には脱酸剂として,
通常 $\mathrm{Mn} か ゙ 0.2 \sim 0.4 \%$ 添加されている. 供試試料は市販 合金を基にして Ce， $\mathrm{Al}, \mathrm{Si}$ を複合添加したもので，高周波 真空溶解炉で溶解し，熱間鍛造，熱間压延，冷間圧延を経 て $0.3 \mathrm{~mm}$ 厚としたものである.

試料の化学組成をTable 1 K示す。試料 1 以市販合金で あるが標準合金として採用した．試料 2 は $\mathrm{Ce} ， \mathrm{Al}, \mathrm{Si}$ を複 合添加したるのである。この試料を $15 \times 30 \mathrm{~mm}$ 切断し， エメリ一研摩紙０4 で仕上げ研摩し，歪とり焼鈍を兼祖 た湿潤水素炉処理を加兄て酸化実験，ガラス封着に供し た. 湿潤水素炬での処理条件は炬温 $1000^{\circ} \mathrm{C}$, 水素露点 10 ${ }^{\circ} \mathrm{C}$, 処理時間 $30 \mathrm{~min}$ とした.

Table 1 Chemical composition of specimens. (wt \%)

\begin{tabular}{c|c|c|c|c|c|c|c|c}
\hline \hline Sample & $\mathrm{Ni}$ & $\mathrm{Co}$ & $\mathrm{Mn}$ & $\mathrm{Ce}$ & $\mathrm{A} 1$ & $\mathrm{Si}$ & $\mathrm{C}$ & $\mathrm{Fe}$ \\
\hline 1 & 29.2 & 17.1 & 0.24 & - & 0.020 & 0.08 & 0.008 & $\mathrm{Bal}$ \\
2 & 29.2 & 17.0 & 0.23 & 0.08 & 0.175 & 0.26 & 0.008 & $\mathrm{Bal}$ \\
\hline
\end{tabular}

大気中での高温酸化は $600 \sim 1200^{\circ} \mathrm{C}$ 間, $50^{\circ} \mathrm{C}$ 間隔で 1〜30 min 行なった。酸化膜の解析としては酸化增量の測 定, 酸化膜のX線回折，化学分析，酸化膜和上び酸化膜と 地金との界面のX線マイクロアナライザによる解析，酸化 膜表面の走查形電子顕微鏡(SEM) とよる観察を行なった。

また，添加元素のガラス封着におよ洔す影響を知るため 硼珪酸がラスとの封着を行ない，封着界面をX線マイクロ アナライザを用いて調べ，酸化膜のガラス中への拡散状態 を観察し，封着強度·封着界面の色調との関係について調べ

* 東京芝浦電気株式会社金属材料事業部(Metal Products Division, Tokyo Shibaura Electric Co., Ltd., Kawasaki) 
た. 封着強度はFig.1に示す形状にガラス封着した試料を アムスラー引張り圧縮試験機で压縮破壊し，そのときの破 壊強度で比較した。 ガラス封着は大気中で $1050^{\circ} \mathrm{C}, 5 \mathrm{~min}$ の条件で行なった，使用した的珪酸がラス ${ }^{(14)}$ の組成を Table 2 に示守.

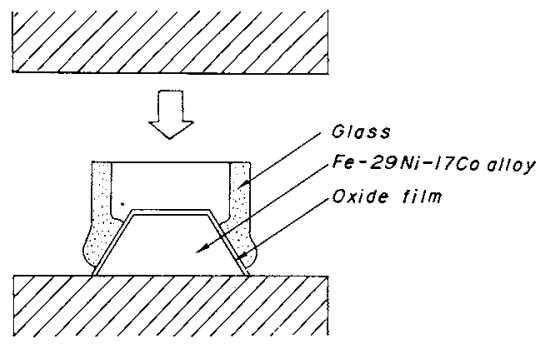

Fig. 1 Schematic diagram of fracture strength measurement in sealing parts.

Table 2 Composition of Boro-Silicate Glass. (wt \%)

\begin{tabular}{c|c|c|c|c|c}
\hline \hline $\mathrm{SiO}_{2}$ & $\mathrm{~B}_{2} \mathrm{O}_{3}$ & $\mathrm{Al}_{2} \mathrm{O}_{3}$ & $\mathrm{Na}_{2} \mathrm{O}$ & $\mathrm{K}_{2} \mathrm{O}$ & $\mathrm{BaO}$ \\
\hline 64 & 18 & 8 & 2 & 4 & 3 \\
\hline
\end{tabular}

\section{III. 実験結果および考察}

\section{1. 酸化条件とガラス封着}

封着体に要求される特性で最も大切なのは気密性と機械 的強度である.Pask(8) は Fe-29 Ni-17 Co 合金の酸化増量 か゚ $0.0003 \mathrm{~g} / \mathrm{cm}^{2}$ 以下では気密性は良いが封着強度は弱く， $0.0007 \mathrm{~g} / \mathrm{cm}^{2}$ 以上では封着強度は強いが酸化膜を通じて のスローリークが生じ易いと述べている.よって0.0003〜 $0.0007 \mathrm{~g} / \mathrm{cm}^{2}$ が良いとしている。

酸化増量を $0.0004 \mathrm{~g} / \mathrm{cm}^{2}$ とした試料とガラスとの封着 を行ない衝撃破壞したとさの標準合金と $\mathrm{Ce}, \mathrm{Al}$, Si 添加合 金の封着強度比較値を Table 3 亿示主，参考のため，前処 理としての湿潤水素炬処理をしないで大気中酸化し封着し た試料(No.3)の值方付記した。

封着強度は彷来の市販合金(標準合金)に比L, Ce, AI, Si 添加合金は約 2 倍の強度を持っている. 湿潤水素炉処理を 行なわないものは行なったものの約半分の強度しか持たな W.

Table 3 Effect of addition elements on the fracture strength in sealing parts.

\begin{tabular}{c|c|c|c}
\hline No. & Sample & $\begin{array}{c}\text { Weight gain } \\
\left(\mathrm{g} / \mathrm{cm}^{2}\right)\end{array}$ & $\begin{array}{c}\text { Fracture } \\
\text { strength } \\
\left(\mathrm{kg} / \mathrm{cm}^{2}\right)\end{array}$ \\
\hline 1 & $\begin{array}{c}\text { Fe-29 Ni-17 Co } \\
\text { alloy }\end{array}$ & 0.00040 & 150 \\
\hline 2 & $\begin{array}{l}\text { Fe-29 Ni-17 Co } \\
\text { alloy containing } \\
\text { Ce, Al and Si }\end{array}$ & 0.00039 & 350 \\
\hline 3 & $\begin{array}{c}\text { Fe-29 Ni-17 Co } \\
\text { alloy }\end{array}$ & 0.00042 & 80 \\
\hline
\end{tabular}

Fe-29 Ni-17 Co 合金では 0.0006 0.0011 g/ $\mathrm{cm}^{2}$ が良い との説 ${ }^{(15)}$ むる。そこで酸化增量と封着強度の関係を調 べた。 その結果をTable 4 に示す. 封着強度に関する限り は酸化増量の多い万が強くなるが $0.0007 \mathrm{~g} / \mathrm{cm}^{2}$ 以上とな ると酸化膜をがラス中に搪散させるいわゆる焼込みが問 題になる。酸化膜が厚いと焼込み不足を生じ易くなり，

Photo.1 に示すように封着後に界面に残留する酸化膜が厚 くなり，気密漏浭の可能性が大きくなってくる。

Table 4 Effect of weight gain on fracture strength measurement in sealing parts of $\mathrm{Fe}-29 \mathrm{Ni}$ 17 Co alloy.

\begin{tabular}{c|c}
\hline Weight gain $\left(\mathrm{g} / \mathrm{cm}^{2}\right)$ & Fracture strength $\left(\mathrm{kg} / \mathrm{cm}^{2}\right)$ \\
\hline 0.0012 & 150 \\
0.0007 & 150 \\
0.0004 & 150 \\
0.0002 & 80 \\
0.0001 & 20 \\
\hline
\end{tabular}

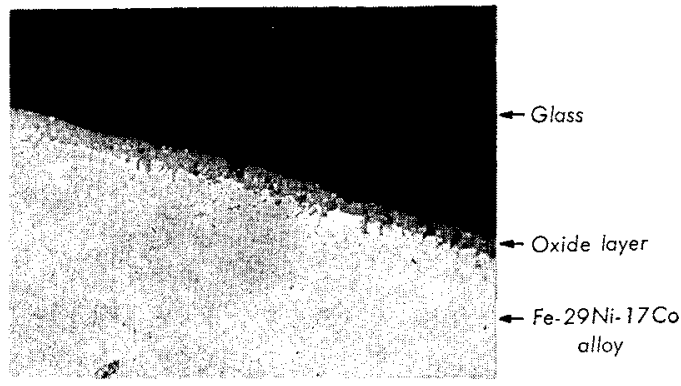

Photo.1 Microphotograph of the oxide layer remained at the interface between $\mathrm{Fe}-29$ $\mathrm{Ni}-17 \mathrm{Co}$ alloy and glass. $(\times 1000 \times 3 / 5)$ oxidation : $1000^{\circ} \mathrm{C}, 5 \mathrm{~min}$ in air sealing : $1050^{\circ} \mathrm{C}, 5 \mathrm{~min}$ in air

金属とガラスを封着し，ガラスを衝撃破壞したとき次の 4 通りの破壊の仕方がある(16)。

(1) 金属地金と酸化膜間で䟝離

(2) 酸化膜層問で㔀離

(3) 酸化膜とガラス間で桪離

（4）ガラス中で破壊が生じ，金属側にガラスが付着した 状態を保っている

衝撃破壊強度が強いのは金属と酸化膜間で跳離すること はなく，金属に酸化膜およびがラスの 1 部が付着した状態 での破㙲が生じたときである。

颙質ガラス湗着用合金として知られる Fe-42 Ni-6 Cr 合 金では湿潤水素中で $\mathrm{Cr}$ を選択酸化し，地金との密着性の 良い酸化膜を作ること，微量添加元素の調整により衝撃破 壞による封着強度を $500 \mathrm{~kg} / \mathrm{cm}^{2}$ とすることも可能であ る(13).これに比し，Fe-29 Ni-17 Co 合金では封着强度は $350 \mathrm{~kg} / \mathrm{cm}^{2}$ にしか達しない，破壊後，ガラスが金属に付 着している面積比は標準合金では50\%に達することはは とんどないが， Ce， Al，Si 添加合金では $90 \%$ に達するこ ともある。 


\section{2. 添加元素の酸化速度，酸化膜組成に及ぼす影響}

$\mathrm{Fe}-29 \mathrm{Ni}-17 \mathrm{Co}$ 合金を大気中で高温酸化すると 2 乗則に 従って進行することが報告されている(11)(15)．Fig.2 に湿 潤水素炉処理を行なった標準合金の酸化条件と酸化增量の 関係を示すが，この場合にも2 委則に従うことがわかる。 $\mathrm{Ce}, \mathrm{Al}, \mathrm{Si}$ 添加合金の酸化も2 乗則従って進行する.

Fig.2の内，×印でプロットしたのは高温酸化後の泠却 過程て酸化膜が䟝離したものである。これに対し， Ce, $\mathrm{Al}$ ， Si 添加合金では全域にわたって酸化膜の䟝離は皆無で あった。

Fig.3 に酸化速度定数と $1 / T$ との関係を示す. 活性化工

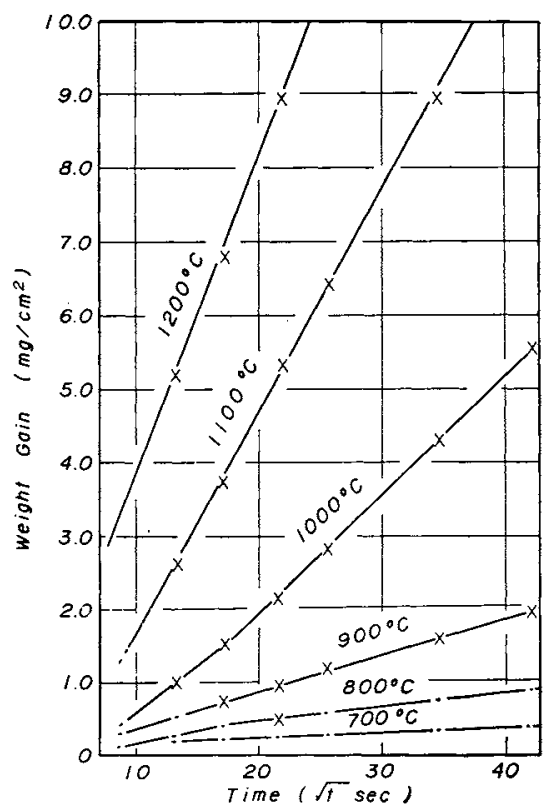

Fig.2 Oxidation of $\mathrm{Fe}-29 \mathrm{Ni}-17 \mathrm{Co}$ alloy in air after treatment in wet hydrogen.

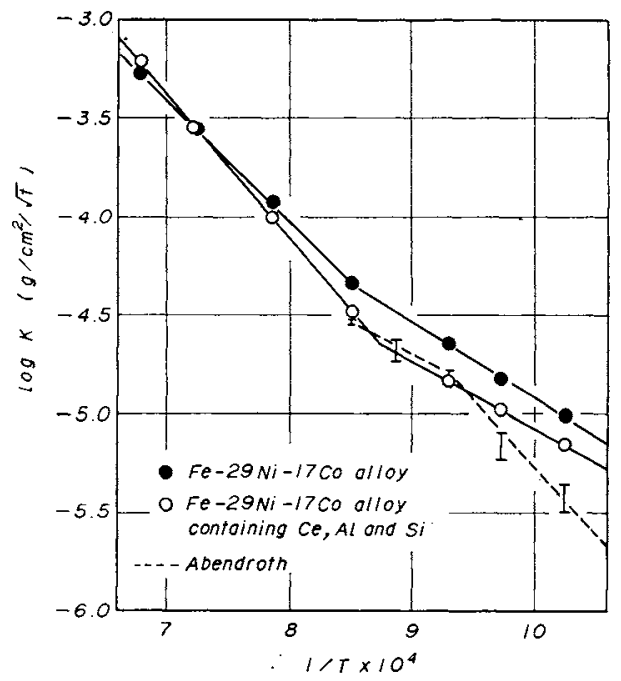

Fig.3 Temperature dependence of oxidation rate in air after treatment in wet hydrogen.
ネルギーは標準合金では約 $900^{\circ} \mathrm{C}$ を境として変わり，高

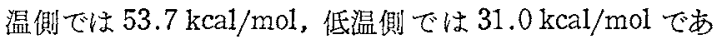
るのに比し， $\mathrm{Ce}, \mathrm{Al}, \mathrm{Si}$ 添加合金では約 $850^{\circ} \mathrm{C}$ 境として 変わり，高温側では $61.9 \mathrm{kcal} / \mathrm{mol}$ ，低温側では $28.7 \mathrm{kcal}$ mol となっている.Fig.3にAbendroth ${ }^{(15)}$ の求めた値を 多併せて示したが $700 \sim 800^{\circ} \mathrm{C}$ 間は $57.6 \mathrm{kcal} / \mathrm{mol}, 800$ $900^{\circ} \mathrm{C}$ 間は $30.9 \mathrm{kcal} / \mathrm{mol}$ としている. Abendroth の值 とは全く逆の傾向を示しているが，これは前処理の違いの 影響によるものか，試料の組成の違いによるものかはわか Бない.

$\mathrm{Ce}, \mathrm{A1}$, Si 添加合金の酸化膜のX線回折結果学 Fig.4 K 示主。酸化膜の組成は $\alpha-\mathrm{Fe}_{2} \mathrm{O}_{3}, \mathrm{Fe}_{3} \mathrm{O}_{4}, \mathrm{CoO} \cdot \mathrm{Fe}_{2} \mathrm{O}_{3}$ を主成 分とするものであるが，酸化初期では $\mathrm{Fe}_{3} \mathrm{O}_{4}, \mathrm{CoO} \cdot \mathrm{Fe}_{2} \mathrm{O}_{3}$ のスピネル型酸化物の占める割合が多く，酸化が進さにつ れて $\alpha-\mathrm{Fe}_{2} \mathrm{O}_{3}$ の占める割合が多くなって来る。このことは 標準合金において子同じであるが，Ce, A1，Si 添加合金偟 比し，全体的に $\alpha-\mathrm{Fe}_{2} \mathrm{O}_{3}$ の占める割合が多い。このことは 低温ではより影著である。

漂準合金と Ce, Al, Si 添加合金をそれぞれ湿潤水素则処 理し，大気中で $900^{\circ} \mathrm{C} 5 \mathrm{~min}$ 間加熱し，生成した酸化膜の

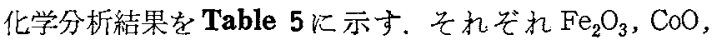
$\mathrm{NiO}, \mathrm{MnO}, \mathrm{Al}_{2} \mathrm{O}_{3}, \mathrm{SiO}_{2}$ の形で組成此を求めた。 $\mathrm{Fe}_{2} \mathrm{O}_{3}$ は 全体の $85 \%$ 以上を占めて抢り主成分となっている，次い で $\mathrm{CoO}, \mathrm{NiO}$ の順となっており， $\mathrm{MnO}, \mathrm{SiO}_{2}, \mathrm{Al}_{2} \mathrm{O}_{3}$ の微量 添加元素の酸化物の占める割合少少ない，Ce は酸化膜中 からは検出できなかった、 $\mathrm{Ce}, \mathrm{A} 1, \mathrm{Si}$ 添加合金の酸化膜は 標準合金に比し， $\mathrm{CoO}$ の占める割合はわずかに多い，COO
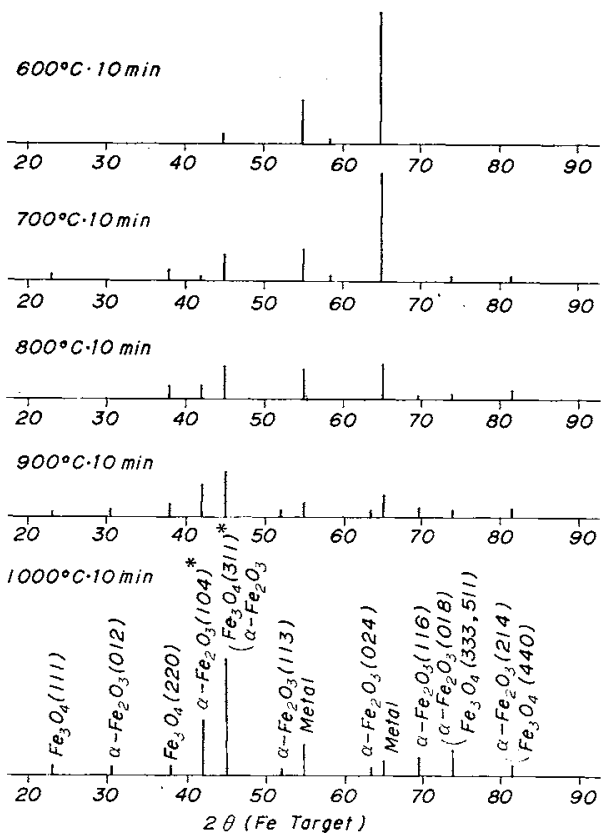

Fig.4 X-ray diffraction patterns of oxide film on Fe-29 Ni-17 Co alloy containing Ce, $\mathrm{AI}$ and Si oxidized in air. $\left(*: I / I_{0}=100\right)$ 
Table 5 Composition of the oxide formed on $\mathrm{Fe}-29 \mathrm{Ni}-17 \mathrm{Co}$ alloys. (wt\%)

\begin{tabular}{c|c|c|c|c|c|c}
\hline Sample & $\mathrm{NiO}$ & $\mathrm{CoO}$ & $\mathrm{MnO}$ & $\mathrm{SiO}_{2}$ & $\mathrm{Al}_{2} \mathrm{O}_{3}$ & $\mathrm{Fe}_{2} \mathrm{O}_{3}$ \\
\hline $\begin{array}{l}\mathrm{Fe}-29 \mathrm{Ni}-17 \mathrm{Co} \\
\text { alloy }\end{array}$ & 2.63 & 7.8 & 0.32 & Trace & 0.02 & $\mathrm{Bal}$ \\
\hline $\begin{array}{l}\mathrm{Fe}-29 \mathrm{Ni}-17 \mathrm{Co} \\
\text { alloy contain- } \\
\text { ing Ce, Al and } \\
\mathrm{Si}\end{array}$ & 3.22 & 10.0 & 0.30 & 0.52 & 0.20 & $\mathrm{Bal}$ \\
\hline
\end{tabular}

はX線回折の結果 $\mathrm{CoO} \cdot \mathrm{Fe}_{2} \mathrm{O}_{3}$ の形で存在することが明ら かであり，Ce， Al，Si 添加合金の方がスピネル型酸化物に 富んでいることとも一致している.

\section{3. $\mathrm{X}$ 線マイクロアナライザによる酸化膜断面の検討}

標準合金を大気中で $900^{\circ} \mathrm{C}, 5 \mathrm{~min}$ の酸化をした試料断 面をX線マイクロアナライザで走查した結果をFig.5に示 す. 酸化膜の主成分は $\alpha-\mathrm{Fe}_{2} \mathrm{O}_{3}, \mathrm{Fe}_{3} \mathrm{O}_{4}, \mathrm{CoO} \cdot \mathrm{Fe}_{2} \mathrm{O}_{3}$ である ことはX線回折，化学分析で確認したが，Fig.5(a)でも酸 化膜の大部分は $\mathrm{Fe}$ の酸化物であることがわかる. Al, Si は酸化膜中ではかえって減少している. Fig.5 (b) 上り Co,
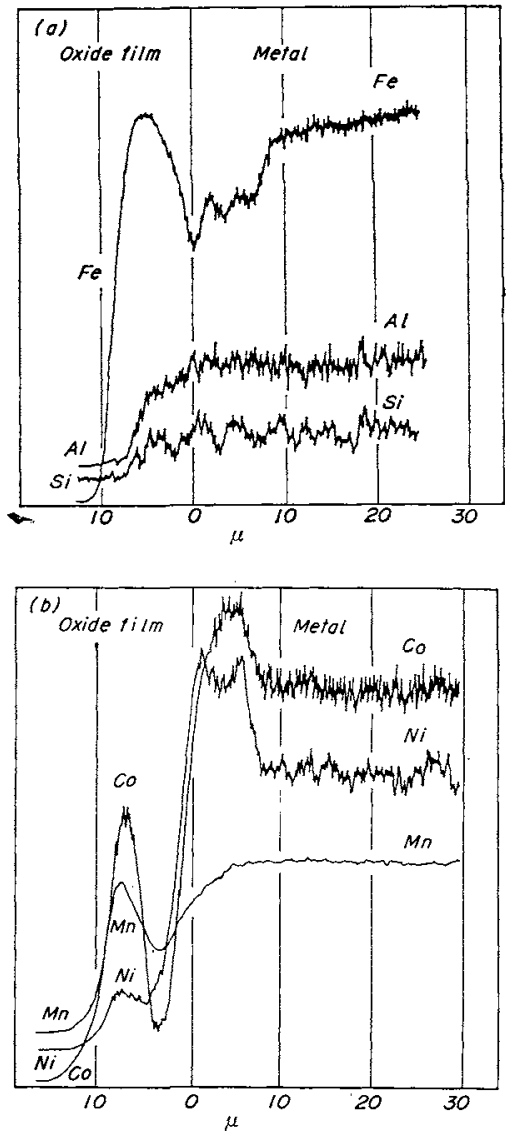

Fig.5 Distributions of each element, scanning from the metal to the oxide film, on $\mathrm{Fe}-29 \mathrm{Ni}-17 \mathrm{Co}$ alloy oxidized in air $\left(900^{\circ} \mathrm{C}, 5 \mathrm{~min}\right)$.
$\mathrm{Mn}$ は選択酸化し，両元素之す酸化膜の表面層に多く集ま っているのが認められる.Ni の酸化は慓と儿ど認められ ない．これは化学分析の結果ともよく一致している.

$\mathrm{Ce}, \mathrm{Al}, \mathrm{Si}$ 添加合金を標準合金と同一条件で酸化した試 料断面をX線マイクロアナライザで走査した結果をFig.6 に示す. Fig.6(a)に Fe, Al, Si を走査した結果を示す. Fe の濃度分布は標準合金と注涪同じであるが，Si は酸化 膜と合金地金との間似多く集まり，選択酸化層を作ってお り，内部酸化も見られる，また，A1 は内部酸化と酸化膜 表面層にいくらか集まっているのが見られる．Fig.6(b)に $\mathrm{Co}, \mathrm{Ni}, \mathrm{Mn}$ の走查結果を示すが傾向は標準合金の結果と ほ济同じである.Coの酸化物はわずかではあるが標準合 金に比し多く見られる.

酸化膜と地金との界面のX線マイクロアナライザによる 走査で，標準合金と Ce, A1, Si 添加合金の最も大きな違い は $\mathrm{Al}, \mathrm{Si}$ の挙動である. 即ら, 標準合金汇も微量の $\mathrm{Al}, \mathrm{Si}$ は含まれてはいるが，酸化にははとんど関係していないの 飞比し， $\mathrm{Ce}, \mathrm{Al}, \mathrm{Si}$ を複合で添加した合金では $\mathrm{Al}$, Si は内 部酸化し，地金々酸化膜の界面で $\mathrm{Si}$ の選択酸化層が見ら
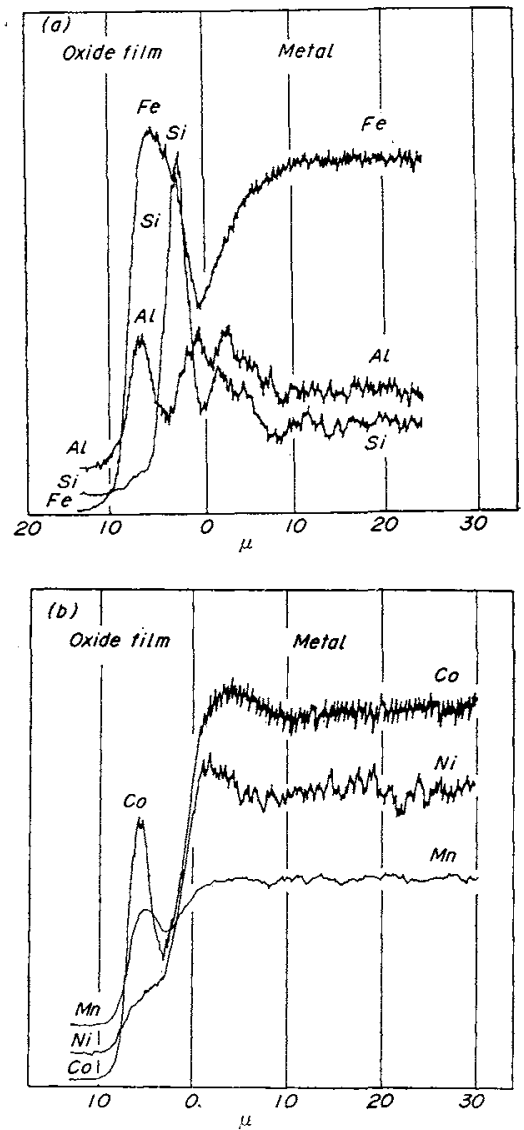

Fig.6 Distributions of each element, scanning from the metal to the oxide film, on $\mathrm{Fe}-29 \mathrm{Ni}-17 \mathrm{Co}$ alloy containing $\mathrm{Ce}, \mathrm{Al}$ and $\mathrm{Si}$ oxidized in $\operatorname{air}\left(900^{\circ} \mathrm{C}, 5 \mathrm{~min}\right)$. 
れること，酸化膜表面層に $\mathrm{Al}$ の集積が認められることで ある.この Al, Si の挙動が合金の過酸化を防此し，酸化膜 と地金との密着性を良くし，高温酸化後冷却しても酸化膜 が地金から㔀離することが無くなるものと考壳られる。

ステンレス鋼に Ce を添加すると酸化膜と地金との密着 性は良くなる(17)が，Fe-29 Ni-17 Co 合金炕拈いて子 Ce， $\mathrm{Al}, \mathrm{Si}$ を複合添加すると同じ効果があるものと考方られ る.

\section{4. ガラスとの封着界面}

酸化膜と地金との密着性が要求されるのは，ガラスとの 封着強度は酸化膜と地金との付着強度と相関関係があるか らである。がラスとの封着作業は酸化膜をがラス中に適度 に拆散させる(焼込む)ことによって完了する(18)(19)．この とき，金属とガラスとの界面がぞのような構造になってい るかを知ることは大切である。

標準合金とガラスとの封着界面をX線マイクロアナライ ザで走査した結果をFig.7亿示す，Fig.7 (a) に Fe，Al，Si を走査した結果を示すが，Feはがラス中仙よく拡散し， Fe の拡散膡ではガラス中の Al, Si はその分減少している
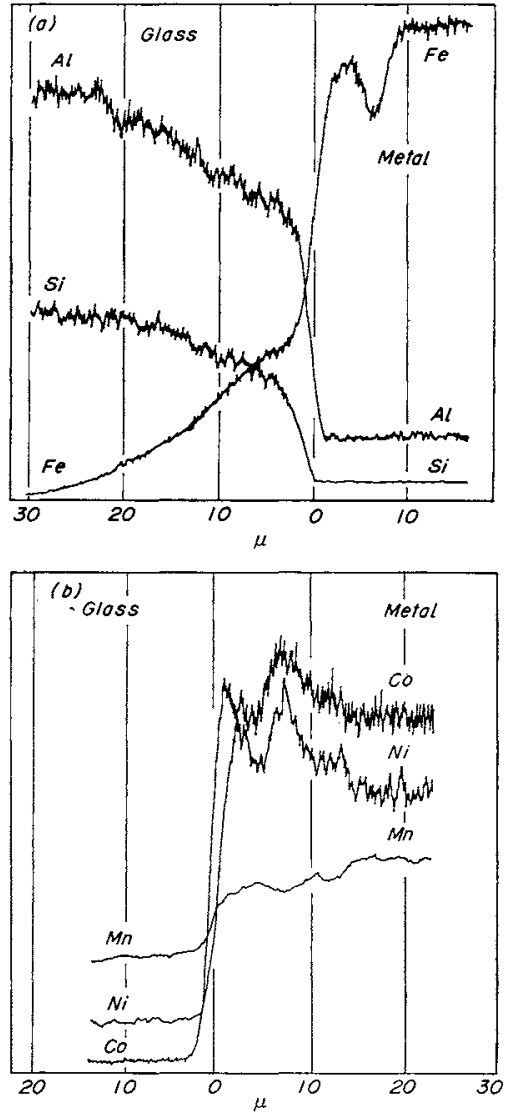

Fig.7 Distributions of each element, scanning from the metal to the glass, on $\mathrm{Fe}-29$ $\mathrm{Ni}-17 \mathrm{Co}$ alloy. (oxidation $900^{\circ} \mathrm{C}, 5 \mathrm{~min}$ in air sealing $1950^{\circ} \mathrm{C}, 5 \mathrm{~min}$ in air)
のが認められる．Fig.7(b)にCo，Ni，Mn を走査した結果 を示すが，Co はガラス中によく拡散し，酸化膜表面層に あった Co の酸化物層は完全に消失し，Mn む上く拡散し ているのが認められる。

$\mathrm{Ce}, \mathrm{Al}, \mathrm{Si}$ 添加合金とガラスとの封着界面をX線マイク ロアナライザで走査した結果を Fig.8 に示す. Fig.8(a) に $\mathrm{Fe}, \mathrm{Al}$ ，Si を走查した結果を示すが，Fe は標準合金の場合 と同じくガラス中によく拡散している. ガラス中の A1, Si は合金地金に近づくに従って濃度が減少しているのは標準 合金と同じであるが，合金との界面で内部酸化層も含めた $\mathrm{A} 1, \mathrm{Si}$ の選択酸化層に繋がっている. Fig.8(b) に Co, Ni, Mn を走査した結果を示すが，Co はガラス中によく拡散 し，CＯの酸化物層が消失している点，Mn もガラス中に よく拡散している点等，標潐合金の場合と同じである.

従来より，金属とガラスとの封着の良し悪しは封着界面 の色調(20)で判断されることが多い，Fe-29 Ni-17 Co 合金 とガラスとの封着界面の色は灰色が最も適当とされてい る. 界面に残るわずかな酸化膜により灰色を旺するわけで あるが， $\mathrm{Ce}, \mathrm{Al}, \mathrm{Si}$ 添加合金ではこの灰色を呈する作業範
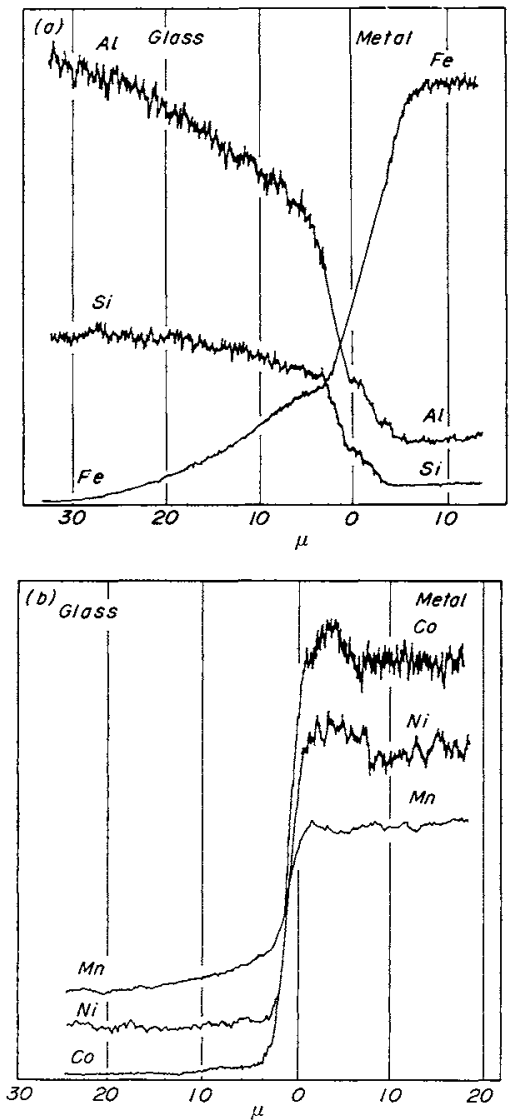

Fig.8 Distributions of each element, scanning from the metal to the glass, on $\mathrm{Fe}-29$ $\mathrm{Ni}-17 \mathrm{Co}$ alloy containing $\mathrm{Ce}, \mathrm{Al}$ and Si. (oxidation $900^{\circ} \mathrm{C}, 5 \mathrm{~min}$ in air sealing $1050^{\circ} \mathrm{C}, 5 \mathrm{~min}$ in air) 
囲(封着時の加熱温度幅，加熱時間幅)は標準合金比し， はるかル広い、標準合金と $\mathrm{Ce}, \mathrm{Al}, \mathrm{Si}$ 添加合金との違い は，X線マイクロアナライザによる走查結果で，合金内部 扝よび界面に存在する $\mathrm{Al}$ 扎よび $\mathrm{Si}$ の酸化物層にあるこ とがわかる. AI 拈よび Si の酸化物が酸化膜と地金との付 着強度を強くすること， $\mathrm{Fe}, \mathrm{Co}, \mathrm{Mn}$ の酸化物が完全にガ ラス中に拡散してもこの $\mathrm{Al}$, Si の酸化物は金属とガラス との界面に最後まで残りガラスと金属地金間の中間層の徍 割りを果し，結びつきを強め，镁着強度を強くするものと 考えられる。

$\mathrm{Al}, \mathrm{Si}$ の酸化物層の影響は接触角によっても裹付计られ る. 封着界面にわずかに酸化物層が残っている状態での標 準合金と硼理酸がラスとの接触角は $43^{\circ}$ であるが Ce, Al, $\mathrm{Si}$ 添加合金では $28^{\circ}$ と小さくなっている. 高温酸化しない 金属純鉄とガラスとの接触角は $55^{\circ}$ で(21)，七ラミックとガ ラスとのなじみは非常に良く接触角は 00 である(22)。いず れの合金も接触角が $55^{\circ}$ 以下なのは金属とガラスとの界面 に存在する酸化物の影響であろう、標準合金では主として Fe の酸化物加残留し， Ce, Al, Si 添加合金では Fe の酸化 物以外に $\mathrm{A} 1, \mathrm{Si}$ の酸化物も存在する. Fe の酸化物に関し ては同一条件下にあり，Ce，A1，Si 添加合金の接触角の小
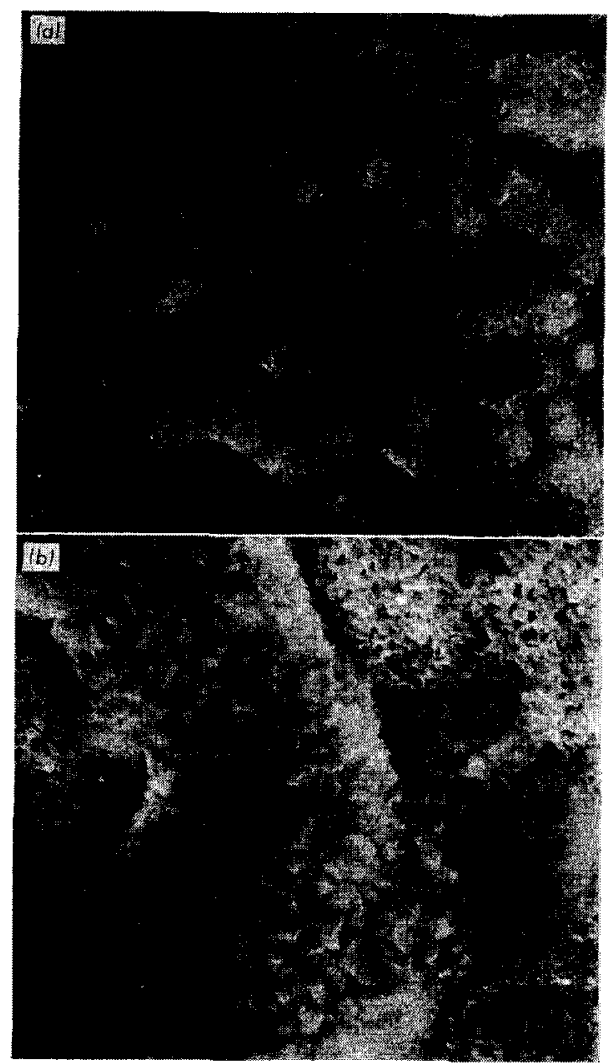

Photo.2 Scanning electron micrographs of the surface of $\mathrm{Fe}-29 \mathrm{Ni}-17 \mathrm{Co}$ alloy oxidized in air. $(\times 5000 \times 3 / 5)$

(a) $700^{\circ} \mathrm{C}, 3 \mathrm{~min}$, (b) $900^{\circ} \mathrm{C}, 10 \mathrm{~min}$
さいのは界面に存在する A1, Si の酸化物の影響と考えら れる。

\section{5. 酸化膜の表面状態}

標準合金の酸化膜の成長過程を SEM で観察した結果を Photo. 2 に示す。酸化初期では酸化物が網目状に盛り上っ ているのが認められる。スピホル型酸化物が増えるにつれ て盛り上がった部分も増えていることから，この盛り上が った部分はスピホル型酸化物に富んだ酸化物が主成分をな しているものと考えられる，低温て酸化する葟ど絧目は細 かく，高温になると網目は粗くなり，盛り上がった部分の 幅は広くなり，絧目およびマトリックスを形成する酸化物 の結晶は大きくなってくる. $900^{\circ} \mathrm{C}$ の酸化では網目をなし ているが $1050^{\circ} \mathrm{C}$ の酸化では全面がブロック状の酸化物の 結晶に覆われ，網目は明瞭には譛められなくなる。

酸化に供した試料は湿潤水素中で $1000^{\circ} \mathrm{C}, 30 \mathrm{~min}$ の峦 鈍を行なったものであり，地金の結晶粒の大ささは直径

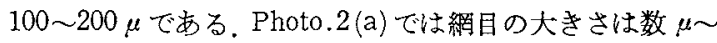
$20 \mu$ くらいであり, (b) では 15 50 $\mu$ くらいである. (a)

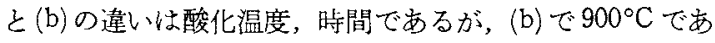
り，酸化処理での地金の結晶粒の成長はほとんど認められ

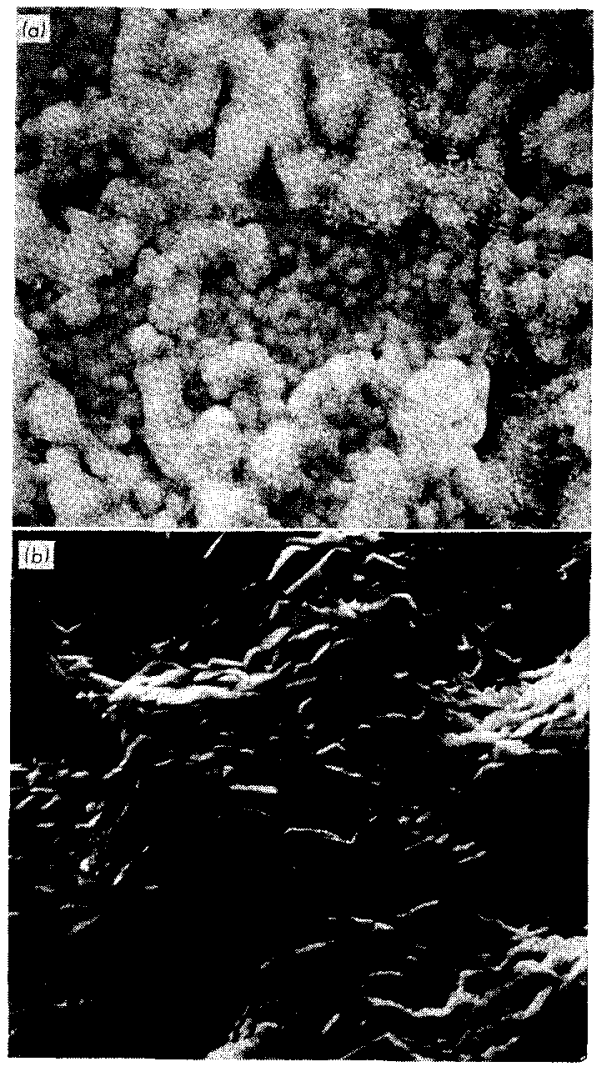

Photo. 3 Scanning electron micrographs of surface of $\mathrm{Fe}-29 \mathrm{Ni}-17 \mathrm{Co}$ alloy containing $\mathrm{Ce}, \mathrm{A} 1$ and $\mathrm{Si}$ oxidized in air. $(\times 5000 \times 3 / 5)$ (a) $700^{\circ}, 3 \mathrm{~min}$, (b) $950^{\circ} \mathrm{C}, 5 \mathrm{~min}$ 
ない。このことから酸化物の盛り上りは地金の粒界酸化の みによるるのとは考光難い.

$\mathrm{Ce}, \mathrm{Al}, \mathrm{Si}$ 添加合金の酸化膜の成長過程の観察結果を Photo.3 に示す，低温で酸化すると絧目状火酸化物が盛り 上がるのが見られる点, 高温になるとブロック状の酸化物 で覆われる点とも標準合金の場合と同じである，低温での 酸化でマトリックス部に無数の小さな半球状の酸化物の盛 り上がりが見られるがこれは標準合金では見られない。

酸化膜の盛り上がった部分とマトリックス部分とでは膜 厚は異なる，酸化物の組成によりガラス中への应散速度は 当然異なるが，このような酸化膜の部分的な厚さの違い， 組成の違いはガラスとの封着後の酸化膜の残留の仕方にす 影劉してくるものと考えられる。

\section{IV. 結論}

硬質ガラス封着用合金として用いられているFe-29 Ni$17 \mathrm{Co}$ 合金の高温酸化，ガラスとの封着性におよ济す Ce， $\mathrm{Al}$, Si の添加効果について調べた。この結果, Ce, A1, Si 添 加合金では無添加の合金に比しかなりの封着強度の向上が 見られた.この原因究明のため，合金の酸化機構について 調べ次の結諭を得た。

(1) Ce, Al, Si 添加合金は無添加の合金に比し，金属地 金と酸化膜との付着強度ははるかに強い，無添加の合金で 見られる高温酸化後の泠却過程での地金と酸化膜との䠌離 は生じない.

(2) Ce, Al, Si 添加合金で法酸化膜と地金との間に Si の 選択酸化層が，合金の表面層近くに $\mathrm{Al}, \mathrm{Si}$ の内部酸化層 が見られる。この $\mathrm{Si} の$ 選択酸化層， $\mathrm{Al}$, Si の内部酸化層 が地金と酸化膜の付着強度向上に笴与しているものと考兵 られる。

(3) $\mathrm{Ce}, \mathrm{Al}, \mathrm{Si}$ 添加合金, 無添加の合金とも酸化膜の主 成分は $\alpha-\mathrm{Fe}_{2} \mathrm{O}_{3}, \mathrm{Fe}_{3} \mathrm{O}_{4}, \mathrm{CoO} \cdot \mathrm{Fe}_{2} \mathrm{O}_{3}$ である。酸化の初期で はスピネル型酸化物は網目状盙り上り，成長するにつれ 幅を広げていく，高温ではブロック状の酸化物が成長す る.

（4）ガラス封着したとき， $\mathrm{Fe}$, Co の酸化物はガラス中 によく㹡散する，Ce，Al，Si 添加合金ではガラスとの封着 時に加熱処理をオーバーに行なっても Si の酸化層， Al，Si
の内部酸化層は界面に残り，封着強度の向上に役立ってい る.

(5) 酸化の活性化エネルギは Ce, A1, Si 添加合金で は約 $850^{\circ} \mathrm{C}$ で変化し，高温側では $61.9 \mathrm{kcal} / \mathrm{mol}$ ，低温側

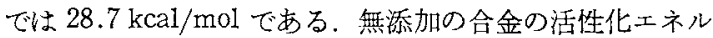
ギは約 $900^{\circ} \mathrm{C}$ で変化するが值は類似している，酸化速 度は $1100^{\circ} \mathrm{C}$ 以下では Ce, Al, Si 添加合金の方が僬い。

終りに本研究を行ならに当り，有益な御助言を賜わった 東京大学工学部 久松敬弘教授，増子 昇助教授に深〈感 謝の意を表します。

\section{文献}

(1) H.Scott, E. Pittsburgh : Trans. AIME, (1930), 506 .

(2) H.Scott : JFI, 218(1935), 733.

(3) L.L.Wyman : Trans.AIME, 135(1939), 542.

(4) W.H.Kohl : Materials Technology for Electron Tubes, Reinhold, (1950), 82.

(5) J.H.Partridge : Glass to Metal Seals, Society of Glass Technology, (1967), 18.

(6) 三戸 暁：金属学会誌，20(1956)，566.

（7）三户 䀘：金属学会誌，24(1960)，790.

(8) J.A.Pask : Proc.IRE, 36(1948), 286.

(9) 小野員正：応用物理, $25(1956) ， 500$.

(10) A.W.Hull, E.E.Burger and L.Nauias: J.Appl. Phys., 12(1941), 698.

（11）池田 豐：案業協会誌，72(1964)，29.

(12) M.R.Natis : J.Amer.Ceram.Soc., 45(1962), 412.

（13）久世 孝, 岩井直次, 幕内昭司：金属学会誌，37 (1973), 272.

(14) 森谷太郎, 成瀬 省綟：ガラス工学ハンドブック， 朝倉書店, (1963)，537。

(15) R.P.Abendroth : M.R.S., 5(1965), 459.

(16) J.H.Partrige : Glass to Metal Seals, Society of Glass Technology, (1967), 216.

(17) 中心忠行：高温酸化持よび高温腐食シンポジゥム予 稿集，金属学会，(1971)，20.

(18) 久世 孝，奥田徤二，岩井直次：日本電子材料技術 協会会報, 5(1972)，18.

(19) W.H.Koh1 : Materials Technology for Electron Tubes, Reinhold, (1953), 63.

(20) J.H.Partrige : Glass to Metals Seals, Society of Glass Technology, (1967), 200.

(21) R.E.Cline,R.M.Fulrath and J.A.Pask : J.Amer., Ceram. Soc., 44 (1961), 423.

(22) 永井彰一郎編：新しい工業村料の科学，金原出版， (1973), 82 . 